[RADIOCARbon, Vol. 16, No. 1, 1974, P. 10-14]

\title{
FLORENCE RADIOCARBON DATES II
}

C M AZZI

Consiglio Nazionale delle Ricerche, Sezione di Firenze

L BIGLIOCCA, and E PIOVAN

Istituto di Antropologia, Università di Firenze

This list comprises age measurements carried out from October 1972 to July 1973. Samples dated are all of archaeologic interest and come from Italian territory. Pretreatment of samples, production of purest $\mathrm{CO}_{2}$ and counting techniques have been described elsewhere (Azzi, 1972; Azzi et al, 1973).

We have set up a chemical bench to produce $\mathrm{CO}_{2}$ directly from a sample without $\mathrm{CaCO}_{3}$ precipitation (Broecker et al, 1959); we checked this new method with two samples, F-17 and F-45, below. Ages obtained by both methods agree satisfactorily, but we will continue to check the new bench.

Activity of our "modern standard" wood grown near Florence between 1850 and 1870 , was checked with $95 \%$ of NBS oxalic acid counting rate and measurements were found coincident within $1 \sigma$. Age of samples is calculated using the conventional half-life of $5568 \pm 30 \mathrm{yr}$ and is referred to the standard year, 1950. Errors are stated in terms of one standard deviation of counting statistics.

\section{ACKNOWLEDGMENTS}

We thank the Consiglio Nazionale delle Ricerche for providing financial support.

\section{SAMPLE DESCRIPTIONS}

I. ARCHAEOLOGIC AND HISTORIC SAMPLES

\section{Grotta Paglicci series}

\section{A. Italy}

Charcoal and burnt bones from Grotta Paglicci on left side of Settepenne V on S side of Gargano promontory near Rignano Garganico, $15 \mathrm{~km}$ E S Severo, prov Foggia, Apulia (41 $\left.39^{\prime} 8^{\prime \prime} \mathrm{N}, 15^{\circ} 36^{\prime} 51^{\prime \prime} \mathrm{E}\right)$. Coll 1971 and subm 1972 by A Palma di Cesnola, Ist Preist e Protostoria, Firenze, and F Mezzena, Museo Civ di Storia Nat, Verona.

Depth of deposit is, at this point of excavation, nearly $8 \mathrm{~m}$; 21 layers were distinguished. Grotta Paglicci consists in an atrium and a large internal hall, $6 \mathrm{~m} \times 20 \mathrm{~m}$.

Samples dated belong to Layers 18-21. Layers 10 to 16 can be related to Grotta del Romito, Layer 34: 18,750 \pm 350 ( $R$, 1967, v 9, p 358); Ugento, Layer 4 to $7: 14,170 \pm 170 ; 13,870 \pm 110$ (ibid, p 359); Riparo Tagliente (R, 1970, v 12, p 599-601).

\section{F-43. Grotta Paglicei 18, b2 a}

$14,260 \pm 280$

Charcoal from Layer 18, b2. Final Gravettian industry.

$$
12,310 \mathrm{BC}
$$




\section{F-44. Grotta Paglicei 18, b2 b}

$20,200 \pm 305$

Burnt bones from Layer 18, b2, together with charcoal of F-43. Layer contained Final Gravettian industry like Mochi shelter industry, Layer C, and Monte Longo (F-28) industry (R, 1973, v 15, p 483). Comment: F-44 date agrees with stratigraphy; F-43 sample appears contaminated; chemical treatment for 1st sample was: $\mathrm{HCl} 10 \%-\mathrm{NaOH} \mathrm{O} .1 \mathrm{~N}-$ $\mathrm{HCl} 10 \%$; for the 2nd: HCl $10 \%$ for a lst washing, afterwards a strong $\mathrm{HCl}$ leaching till destruction of organic fraction.

F-45. Grotta Paglicei 18, b3

$20,160 \pm 310$ 18,210 BC

Charcoal from Layer 18, b3, Final Gravettian type industry. F-45 was given only standard pretreatment. Date for this sample, with new direct line for $\mathrm{CO}_{2}$ production: 20,380 \pm 350 confirms other date.

\section{F-46. Grotta Paglicei 19, a}

$20,730 \pm 290$

Charcoal from Layer 19, a. Layer 19 is named "transition layer" because upper part is similar to deepest part of Layer 18, and lower part resembles top of Layer 20, linking Final Gravettian to Evolute Gravettian age.

\section{F-47. Grotta Paglicci 20, b} $21,260 \pm 340$

Charcoal from Layer 20, b. Evolute Gravettian type industry. Layer 20 is typologically parallel with Perigordian V, 2 of W Europe.

\section{F-48. Grotta Paglicei 20, ca}

Charcoal from Layer 20, c.

\section{0,270 BC}

\section{F-49. Grotta Paglicci 20, cb}

$22,110 \pm 330$

Burnt bones from Layer 20, c, together with charcoal F-48. Evolute Gravettian age; both samples had standard pretreatment. Difference between 2 ages is not very significant.

F-50. Grotta Paglicei 20, de

$$
22,630 \pm 390
$$

Charcol from Layer 20 , de.

$23,040 \pm 380$

F-51. Grotta Paglicci 21, a

\section{1,090 BC}

Charcoal from Layer 21, a. Evolute Gravettian type industry with blade of "La Font Robert". Typologically parallel with Perigordian V, 1 in W Europe.

F-52. Grotta Paglicei 21, b

$23,470 \pm 370$

Charcoal from Layer 21, b. Same industry as F-51. 


\section{F-53. Grotta Paglicci 21, c

Burnt bones from Layer 21, c. Evolute Gravettian age.

\section{F-54. Grotta Paglicei 21, e}

$23,750 \pm 390$

Charcoal from Layer 21, c, together with charcoal F-53. Difference between ages not very significant.

\section{F-55. Grotta Paglicei 21, d}

Charcoal from Layer 21, d. Evolute Gravettian industry.

\section{S Reparata series (inside)}

Six more samples of charcoal and wood coll and subm 1972 by $\mathrm{F}$ Toker, archaeologist of S Reparata excavation. S Reparata is an Early Christian church beneath the present day Cathedral of Florence, Italy. They form a sequel to Samples F-10 to F-16 (Azzi et al, 1973). Samples were dated to clarify 3 major points about chronology of site: construction date of a large Roman house preceding church, destruction date of house, and foundation date of Early Christian church. The latter was dated stylistically at ca 6th century (Toker, 1972).

\section{F-56. S Reparata, Q N 3}

$$
\begin{array}{r}
1660 \pm 80 \\
\operatorname{AD} 290
\end{array}
$$

Charcoal from a deep stratum very close to foundation of best preserved room of $\mathrm{N}$ side of Roman house. Date in 3rd or 4th century for expansion of $\mathrm{N}$ side is confirmed by other findings.

\section{F-57. S Reparata, H 266, H N I}

$$
1495 \pm 85
$$$$
\text { AD } 455
$$

This charcoal sample was especially significant, having been found below level of mosaic floor and above intact floor of atrium of Roman house. Date could well indicate a period in which house was no longer functioning but before church was built. This date and that of F-58, point to 5 th century for this intermediate period. This has already been suggested by presence of many crude groves on the site, which, in all probability, were erected by the barbarian invaders of Florence ca AD 410 to 490 .

\section{F-58. S Reparata, Q N 5}

$$
1460 \pm 85
$$

Charcoal, from level $-2.61 \mathrm{~m}$, from ruins at NW corner of Roman house. The 5 th century ruins can be explained by hypothesis outlined above for F-57.

F-59. S Reparata, Zone $\mathbf{R}_{2}$

$$
1405 \pm 85
$$

Charcoal from below mosaic level in $\mathrm{S}$ side of Early Christian 
church. Date indicates last possible moment for laying of mosaic floor of church, and accords with stylistically proposed date of early 6th century, but a mid- or late 6 th century date is also possible.

F-60. S Reparata, J 75, J S I

$1805 \pm 95$ AD 145

Charcoal from a low stratum, $-2.40 \mathrm{~m}$, in very disturbed zone just $\mathrm{E}$ of atrium of Roman house in its final stage. Coin and ceramic dating indicate that house was begun in or near Augustus reign, but was evidently enlarged several times. Possibly, this area lay outside the original small house.

\section{F-61. S Reparata, Piazza S Giovanni}

$\mathbf{8 8 0} \pm \mathbf{8 0}$

Large charcoal chunk extracted by the Government Archaeol Service in Florence from a lime preparation pit directly $W$ of site of $S$ Reparata, during excavation between Cathedral and Baptistery of Florence in 1971. Pit was probably not used during construction of Early Christian church and was, instead, part of reconstruction of $S$ Reparata in Early Romanesque style. Documents refer to rebuilding of church in mid-11th century, so that carbon sample is highly relevant.

\section{F-17. S Reparata, Tomb 42 (remeasured)}

$705 \pm 75$

Wood from coffin of Giovanni di Alamanno de'Medici, who died in 1353, was previously ${ }^{14} \mathrm{C}$ dated, almost a century too late (Azzi et al, 1973). Second date falls slightly short of date of death but agrees with age of wood. The age obtained by $\mathrm{CO}_{2}$ direct preparation is: $725 \pm 75$ and agrees very well with radiocarbon date.

\section{F-62. Monate I, piroge}

$$
940 \pm 75
$$

Wood from pirogue discovered in Monate Lake, Varese, Lombardy $\left(45^{\circ} 48^{\prime} \mathrm{N}, 16^{\circ} 14^{\prime} \mathrm{E}\right)$, from a one-piece pirogue (type monoxile), $2.58 \mathrm{~m}$ long, named Monate I. Coll 1971 by Castelletti and subm 1972 by M Mirabella Roberti, Sopr Antichità della Lombardia, Milano. Sample was dated (unpub, awaiting confirmation of date by submitter). First date: $970 \pm 105$, agrees with 2 nd date: $940 \pm 75$. Comment: to extract humic acids from unpub sample, $3 \% \mathrm{NH}_{4} \mathrm{OH}$ was used, and for $\mathrm{F}-62,0.1 \mathrm{~N}$ $\mathrm{NaOH}$ extending treatment until total extraction.

\section{F-63. Monate 2, piroge}

$$
1580 \pm 105
$$

Wood from pirogue discovered in Monate Lake, Varese, Lombardy $\left(45^{\circ} 48^{\prime} \mathrm{N}, 16^{\circ} 14^{\prime} \mathrm{E}\right)$. Sample came from a 1-piece pirogue, $3.85 \mathrm{~m}$ long, named Monate 2. Coll 1971 and subm 1972 by M Mirabella Roberti. 
General Comment on pirogues: the submitter has not furnished any further documented evidence on pirogues. Therefore, we have no other information about depth of discovery and typology of pirogues.

ReFerences

Alessio, M, Bella, F, Bachechi, F, and Cortesi, C, 1967, University of Rome carbon-14 dates V: Radiocarbon, v 9, p 358

Alessio, M et al, 1970, University of Rome carbon-14 dates VIII: Radiocarbon, v 12 , p 599-616.

Azzi, C M, 1972, Costruzione e messa a punto di un impianto per datazioni tramite ${ }^{14} \mathrm{C}$ con il metodo a gas: Riv Sci Preistoriche, v 28, p 196-209.

Azzi, C M, Bigliocca, L, and Piovan, E, 1973, Florence radiocarbon dates I: Radiocarbon, v 15, p 479-487.

Broecker, IW S, Tucek, C S, and Olson, E, 1959, Radiocarbon analysis of oceanic $\mathbf{C O}_{2}$ : Internatl Jour appl Radiation and Isotopes, v 7, p 1-18.

Toker, F, 1972, Gli scavi sotto il Duomo di Firenze: Notiziario di Archeol Medioevale, v 2, p 2-4. 